\title{
In memoriam: Dr. Fernando Bonadeo Lassalle
}

\author{
Mario L. Benati
}

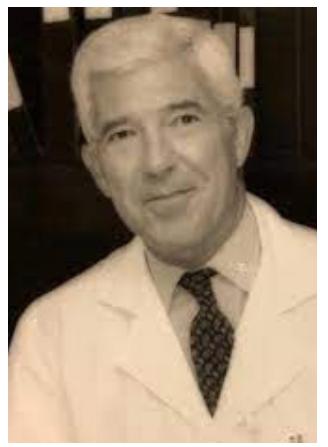

Expresidente de la Academia Argentina de Cirugía

Evocando al Cirujano Maestro Dr. Fernando Bonadeo Lassalle

Enamorado de la Medicina, de la Argentina y del Hospital Italiano de Buenos Aires

El 20 de agosto falleció en su casa, acompañado por su esposa y compañera de toda la vida, sus hijos y nietos. La pandemia en curso impidió que amigos y compañeros, golpeados profundamente, lo despidiesen en la Capilla del HI, como debió ser, y acompañaran sus restos hasta la sepultura.

\section{El médico y su obra}

Su objetivo primero fue hacer el bien al paciente en su totalidad. Le cabe a su accionar fidelidad absoluta al Juramento Hipocrático y la Declaración de Ginebra de la Asociación Médica Mundial. No hubiera podido ser de otro modo para un cristiano creyente como él. Vivió feliz y agradecido. Lo recuerdo diciéndome: "Qué suerte tuvimos al nacer en Argentina". El Hospital Italiano de Buenos Aires fue el lugar propicio que encontró donde desarrollarse. Allí trabajó siempre a tiempo completo.

Una vez concluida su residencia, en 1969, fue invitado a formar parte de lo que sería el grupo original de jóvenes médicos que, bajo la conducción del Dr. Enrique $\mathrm{M}$. Beveraggi, tendrían la misión de lanzar la modernización del Servicio de Cirugía General para que, sin perder cohesión ni atomizarse, se encaminase a la especialización y buscase la excelencia. Ciertamente, un modelo que resultó exitoso. El Dr. Bonadeo llegó a ser años después Jefe del renovado Servicio.

A fines de los años 60, el St. Mark's Hospital de Londres era universalmente considerado el mejor centro de Cirugía Colorrectal. Entusiasmado ante lo que se le presentaba por delante, y dejando opciones más seguras, en 1969 Bonadeo no dudó en viajar y completar su formación viendo en acción a cirujanos como Alan Parks y Henry Thompson, a quien consideraba el mejor. Se interesó además en aspectos anatomopatológicos del cáncer de recto con Basil Morson. A mediados de 1970 regresó al país y comenzó la aventura de crear la Sección de Coloproctología. Ese mismo año yo ingresé al Hospital y Fernando Bonadeo fue mi primer Jefe de Residentes. En 1976 me invitó a trabajar con él y desde entonces fue mi maestro, jefe y amigo. Puedo exhibir con orgullo el haber sido su primer discípulo. Fernando fue un trabajador incansable, dotado de una tremenda fuerza de voluntad que siempre quise poseer y nunca logré. Basado en un concepto científico, académico, docente y de permanente autoevaluación fijó las líneas que debían seguir a rajatabla los integrantes del equipo de Coloproctología: 1) realizar un fichaje exhaustivo de cada paciente con los estudios y procedimientos realizados, evaluar los resultados obtenidos, mostrarlos en diferentes foros y publicarlos; 2) conocer los resultados de centros acreditados, argentinos e internacionales, para compararlos con los propios; 3) dedicar todo el esfuerzo necesario, con personal específicamente contratado, para el seguimiento de los pacientes; 4) estar permanentemente informados de los avances médicos y tecnológicos nacionales e internacionales mediante la lectura de informes, asistencia a cursos, congresosy 
otros foros de discusión, y visitas a centros hospitalarios destacados. Como resultado de la extensa base de datos generada, teniendo en cuenta el alto volumen de pacientes del Hospital Italiano, se han publicado y se seguirán publicando trabajos en la Academia Argentina de Cirugía y otros foros y revistas nacionales e internacionales. Como decía Fernando, debemos estudiar, hacer, registrar, evaluar, leer y escribir. Un ejemplo de rigurosidad científica y voluntad del Dr. Bonadeo lo constituye el haber utilizado fichas perforadas con más de 200 campos para el registro de los pacientes oncológicos. Eran laboriosas para completar y consultar pero prestaron buen servicio hasta la llegada de la informática. El Dr. Germán Welz, hepatólogo del hospital, lo había introducido en su uso.

Fernando Bonadeo fue un excelente cirujano, extremadamente habilidoso; calmo y preciso, no realizaba maniobras innecesarias. Como decía Ricardo Finocchietto, era de los que hacían fáciles cosas que parecían difíciles. Fernando tenía un profundo conocimiento de la patología colorrectoanal en todos sus aspectos pero se destacó especialmente en la cirugía del cáncer de recto. Fueron fascinantes los cambios producidos durante la década del 80 . El foco se centraba sobre la resección anterior baja con conservación esfinteriana. El principal inconveniente era la ejecución de la anastomosis. La aparición de los equipos de sutura mecánica circular fue un avance importante. En 1979, Bonadeo efectuó la primera anastomosis colorrectal mecánica en nuestro hospital. R. J. Heald, un cirujano inglés, publicó en 1982 y 1984 dos trabajos fundamentales que demostraban cómo debía movilizarse el recto para que la cirugía tuviese una baja tasa de recurrencia local. Lo denominó The Holy Plane of Rectal Surgery. Demandaba destreza quirúrgica y especialización y desde el principio fue la elegida por Bonadeo y su grupo. Era impactante verlo encontrar los planos de disección, especialmente en pacientes con anatomía desfavorable o tumores extensos. El acto quirúrgico concluía con el examen macroscópico de las piezas de resección en conjunto con el patólogo y no pocas veces también continuaba con el examen microscópico posterior. Recuerdo que nuestra primera patóloga especializada en colon y recto fue la Dra. Margarita Telenta de Beveraggi. También dominaba las técnicas de resección local. Su conocimiento se extendía a su vez a la interpretación de la imagenología del cáncer de recto, especialmente la resonancia nuclear magnética. Asimismo estaba totalmente informado de lo publicado acerca de los tratamientos adyuvantes y neoadyuvantes que indicábamos a nuestros pacientes. Favorecía la discusión multidisciplinaria de los casos. Era inquisitorio y firme en sus convicciones.

Una decisión importante en los 80 fue que el sector de Coloproctología debía tener alguno de sus integrantes con la capacidad de hacer colonoscopias diagnósticas y terapéuticas. El Dr. Ojea Quintana y yo nos entrenamosy formamos un equipo con el servicio de Gas- troenterología. Esta unión persiste hasta la actualidad. A mediados de los 90 , con el beneplácito de Bonadeo y otros y con su apoyo, Guillermo Ojea Quintana, cirujano brillante y aguerrido, se interesó en el tratamiento de rescate de las recaídas pelvianas del cáncer de recto, cerrando el círculo. Formó un equipo multidisciplinario que creció hasta tratar pacientes con extensión pelviana de neoplasias de otros órganos y realizar cirugía de la carcinomatosis peritoneal.

En 1995 concurrimos con Fernando a San Pablo a un Congreso de la Sociedad Brasileña de Coloproctología y de la ALACP. Asistimos a las presentaciones de Henry T. Lynch acerca del cáncer colorrectal hereditario y vimos la necesidad de desarrollar este tema en nuestro sector. Al regreso, Bonadeo convocó al Dr. Carlos Vaccaro, el más joven del equipo y con buen perfil investigativo, quien hizo un gran trabajo. Ese fue el comienzo del Programa de Cáncer Hereditario que, en el momento actual, tiene categoría institucional y nivel internacional.

Otra elección de Fernando que resultó exitosa y fundamental fue la de la secretaria del sector. La Sra. Alicia Adrover no solamente fue eficiente en la tarea administrativa: siempre cuidó a los pacientes, así como a sus familiares, con trato humano, comprensivo y servicial. También cuidó de nosotros, los médicos del sector.

\section{El médico académico y docente}

Como Miembro Titular de la Asociación Argentina de Cirugía trabajó intensamente. Se desempeñó en la Comisión Directiva, fue director del Curso Anual y director de cursos del Congreso Argentino y de otros cursos organizados por la AAC. Fue nombrado Cirujano Maestro y Miembro Emérito. En el Congreso Argentino de Cirugía de 1991 uno de los Relatos fue "Adelantos en el diagnóstico y en el tratamiento del cáncer del recto y del ano". Ser nombrado Relator es el máximo honor que se le puede conferir a un cirujano en nuestro país. Fernando no era elegible por formar parte de la Comisión Directiva, cosa que el Reglamento de ese momento no permitía y el elegido fui yo. Me sentí muy feliz de representar al Sector de Coloproctología del Hospital Italiano de Buenos Aires. Fernando en su grandeza jamás lamentó el hecho y, por el contrario, demostró complacencia.

Como Miembro Titular de la Sociedad Argentina de Coloproctología, fue Relator del Congreso Argentino y nombrado Cirujano Maestro. En el exterior fue Miembro de la American Society of Colon and Rectal Surgery y miembro honorario de diversas instituciones. Su actividad docente de posgrado fue intensa, y ofreció múltiples conferencias en cursos en la Argentina y en el exterior. Muchos residentes aprendieron cirugía con él y muchos visitantes, argentinos y extranjeros, concurrían a presenciar sus operaciones. Una de sus contribuciones docentes más importantes fue la imple- 
mentación, en 1986, del Curso Internacional de Cirugía Colorrectoanal del Hospital Italiano, que este año cumplirá 18 ediciones y que contó siempre con la asistencia de importantes invitados nacionales y extranjeros. En su momento fue didácticamente novedoso en nuestro medio por basarse en presentaciones cortas, de 15-20 minutos de duración y que naturalmente requerían ser minuciosamente preparadas por los expositores. El modelo fue una réplica del utilizado en el curso de Cirugía Colorrectal de la Universidad de Minnesota, considerado el mejor en ese momento y dirigido por el Dr. Stanley Goldberg.

Fue Presidente de la Academia Argentina de $\mathrm{Ci}$ rugía, el foro de discusión donde más veces Fernando, en momentos de muchos cambios en el tratamiento de las afecciones colorrectales y por ende de opiniones divergentes, presentó trabajos y fundamentó sus aseveraciones con los resultados obtenidos por el sector que lideraba.

\section{Una vida envidiable}

Alguna vez el Dr. Santhat Nivatvongs, de la Universidad de Minnesota y del Memorial Hospital de
Nueva York me confió "Fernando hubiese sobresalido en cualquier Servicio de Cirugía Colorrectal de Estados Unidos". Por suerte nunca pensó en irse del Hospital Italiano de Buenos Aires. Hizo todo lo que se propuso y lo hizo bien. Desde lo médico hasta lo familiar. Su valía profesional y humana lo hizo respetado, escuchado y admirado. En realidad, fue un hombre sencillo, afable y educado. Despertaba empatía en los que lo trataban. En los momentos de distensión promovía un ambiente agradable y utilizaba giros verbales de origen campero, resabios de adolescencia. Un sitio importante para él fue la ciudad de La Cumbre, en Córdoba, donde su familia paterna vacacionaba. Conoció allí a la joven Ana Meincke, con la que se casó y vivió toda su vida. Juntos formaron una hermosa y numerosa familia. Cada vez que podía y en las vacaciones pasaba tiempo en su casa frente al golf. También ese deporte lo practicó bien, llegando a tener 1 de hándicap en su juventud. Indudablemente, La Cumbre fue su lugar en el mundo.

Fernando, tu obra seguirá dando buenos frutos. Quedará en manos de discípulos con tu misma mística que se encargarán a su vez de mantenerla viva en futuras generaciones. Seguramente también tendrás un lugar especial en el Cielo después de hacer tanto bien en la Tierra.

\section{- ENGLISH VERSION}

Evoking master surgeon fernando bonadeo lassalle, md

In Love with Medicine, with Argentina, and with Hospital Italiano de Buenos Aires

On August 20, Fernando died at home surrounded by his wife and lifetime mate, his children, and his grandchildren. The ongoing pandemic prevented deeply shocked friends and colleagues from saying goodbye to him in the HI Chapel, as it should have been, and from accompanying his remains to his grave.

\section{The physician and his work}

His primary goal was to do good to the patient as a whole. His actions were absolutely faithful to the Hippocratic Oath and the Declaration of Geneva of the World Medical Association. It could not have been otherwise for a believing Christian like him. He lived a happy and grateful life. I remember him telling me: "How lucky we are to be born in Argentina." The Hospital Italiano de Buenos Aires was the right place for his professional development. He always worked there, full time.

After completing his residency program in 1969 , he was invited to join what would be the original group of young doctors who, under the leadership of
Enrique M. Beveraggi, MD, would have the mission of launching the modernization of the Department of General Surgery; it would move towards specialization and seek excellence without losing cohesion or atomization. That model certainly proved successful. Years later, Dr. Bonadeo became Chief of the renewed Department.

In the late 1960s, St. Mark's Hospital in London was considered the best center for colorectal surgery worldwide. In 1969, excited by the project ahead -and leaving aside safer options-, Bonadeo did not hesitate to travel and complete his training, seeing surgeons like Alan Parks and Henry Thompson in action -whom he considered the best. He was also interested in the pathology aspects of rectal cancer with Basil Morson. In the mid-1970s, he returned to Argentina and started the adventure of creating the Coloproctology Section. That same year, I started to work in the hospital, and Fernando Bonadeo was my first Chief of Residents. In 1976, he invited me to work with him, and since then he has been my teacher, my chief, and my friend. I can proudly claim to have been his first disciple. Fernando was a tireless worker, with a strong willpower that I always wanted to have but never achieved. Based on a scientific, academic, teaching and ongoing self-evaluated concept, he set out the guidelines to be strictly followed by the members of the coloproctology team: 1 ) to make 
an exhaustive record of each patient including the procedures and tests performed, assess the outcomes, and share them in different forums and publish them; 2 ) to be aware of the outcomes of accredited Argentine and international centers, in order to compare them with their own; 3) to devote every effort to follow-up patients by specifically hired professionals; 4) to be constantly informed of the national and international medical and technological advances by reading reports, attending courses, congresses and other forums of discussion, and visiting leading medical centers. As a result of the comprehensive database, and given the high volume of patients at the Hospital Italiano, papers have been published and will continue to be published in the Argentine Academy of Surgery and other national and international forums and journals. As Fernando used to say, we must study, do, record, assess, read, and write. An example of Dr. Bonadeo's scientific rigor and willingness is the use of perforated cards with more than 200 fields for the registry of oncology patients. They were difficult to complete and consult, but were useful until computers arrived. Hospital's hepatologist Germán Welz, MD, had introduced Fernando to the use of those cards.

Fernando Bonadeo was an excellent, extremely skilled surgeon; calm and precise, he did not perform unnecessary maneuvers. As Ricardo Finocchietto pointed out, Fernando was one of those who made difficult things look easy. Fernando had a deep knowledge of all aspects of colorectal pathology, but stood out especially in rectal cancer surgery. The changes that took place during the 80 's were fascinating. The focus was on low anterior resection with sphincter preservation. The main disadvantage was the execution of the anastomosis. The emergence of the circular mechanical suture was an important step forward. In 1979, Bonadeo performed the first mechanical colorectal anastomosis in our hospital. In 1982 and 1984, R. J. Heald, an English surgeon, published two seminal works demonstrating how the rectum should be mobilized for surgery to have a low rate of local recurrence. He called it The 'Holy Plane' of Rectal Surgery. The technique required surgical skill and specialization, and it was adopted by Bonadeo and his group from the very beginning. It was striking to see him find the dissection planes, particularly in patients with unfavorable anatomy or large tumors. Surgery concluded with the macroscopic examination of the resected pieces with the pathologist, and sometimes continued with the subsequent microscopic examination. I remember that our first pathologist specialized in colon and rectum was Margarita Telenta de Beveraggi, MD. Fernando was also an expert in local resection techniques. His knowledge also included the interpretation of rectal cancer imaging, especially magnetic resonance imaging. He was also fully informed of the publications about the adjuvant and neoadjuvant therapies that we indicated to our patients. He encouraged multidisciplinary discussion of cases. He was inquisitive and stood firm in his convictions.

In the 1980s, an important decision was that some of the members of the coloproctology sector should be able to perform diagnostic and therapeutic colonoscopy. Dr. Ojea Quintana and me trained and built a team with the Gastroenterology Service. This union persists today.

In the mid-1990s, with the support and approval of Bonadeo, Guillermo Ojea Quintana, a brilliant and seasoned surgeon, was interested in the rescue treatment of pelvic recurrence rectal cancer, closing the circle. He built a growing multidisciplinary team to treat patients with pelvic extension of neoplasms from other organs and to perform surgery for peritoneal carcinomatosis.

In 1995, Fernando and I attended a congress of the Brazilian Society of Coloproctology and the ALACP, in São Paulo. We attended Henry T. Lynch's presentations about hereditary colorectal cancer, and saw the need to develop this topic in our sector. Back in Argentina, Bonadeo called Dr. Carlos Vaccaro, the youngest in the team and with a good research profile, who did a great job. That was the beginning of the Hereditary Cancer Program, which now has institutional status and international level.

The secretary of the sector was another successful and fundamental choice of Fernando. Mrs. Alicia Adrover not only was efficient in the administrative task but also cared for the patients their families with humane, compassionate and helpful treatment. She also took care of us, the physicians of the sector.

\section{The physician as academic and teacher}

He worked very hard as Full Member of the Argentine Association of Surgery (AAC). He served the Board of Directors, he was the director of the Annual Course and directed courses of the Argentine Congress and other courses organized by the AAC. He was named Master Surgeon and Member Emeritus. In the 1991 Argentine Congress of Surgery, one of the lectures was "Advances in the diagnosis and treatment of colorectal cancer". Being appointed Lecturer is the highest honor that can be bestowed on a surgeon in Argentina. Fernando was not eligible because he was part of the Board of Directors, and regulations at that time did not allow it; therefore, I was chosen. I was very happy to represent the Coloproctology Sector of the Hospital Italiano de Buenos Aires. In his greatness, Fernando never regretted that fact; on the contrary, he showed complacency.

As a Full Member of the Argentine Society of Coloproctology, he was Lecturer at the 
Argentine Congress, and he was appointed Master Surgeon. Internationally, he was member of the American Society of Colon and Rectal Surgeons, and an honorary member of several institutions. His postgraduate teaching activity was intense, and he gave many lectures in courses in Argentina and abroad. Many residents learned surgery with him, and many colleagues from Argentina and from abroad came to watch his surgeries. One of his most important teaching contributions was the implementation of the International Course on Colorectal Surgery of the Hospital Italiano in 1986. This year, the event celebrates its $18^{\text {th }}$ edition, and it has always been attended by renowned national and international guests. At the time, the course introduced a novel didactic model based on short presentations (15-20 minutes) that, of course, required to be carefully prepared by the speakers. The method was a replica of the one used in the course on Colorectal Surgery at the University of Minnesota, considered the best at that time and directed by Stanley Goldberg, MD.

Fernando was President of the Argentine Academy of Surgery, the discussion forum where Fernando presented more works in times of many treatment changes in colorectal conditions -and therefore of divergent opinions-, and supported his assertions with the results obtained by the sector that he was leading.

\section{An enviable life}

Santhat Nivatvongs, MD, from the University of Minnesota and the Memorial Hospital in New York once told me: "Fernando would have excelled in any Department of Colorectal Surgery in the United States". Fortunately, he never thought of leaving the Hospital Italiano in Buenos Aires. He did everything he intended to do and he did it well, both in his medical and family environments. He was respected, listened and admired due to his professional and human value. Indeed, he was a simple, affable and educated man. He aroused empathy in those who treated him. In moments of relaxation, he promoted a pleasant atmosphere and used turns of phrases of rural origin, remnants of his adolescence. A significant place for him was the city of La Cumbre, in the province of Córdoba, where his father?s family used to go on vacation. It was there that he met young Ana Meincke; they got married, and lived together all his life. They had a large and wonderful family. Whenever he had some spare time on vacation, he used to play golf. He was also a good golfer, reaching 1 handicap in his youth. Undoubtedly, La Cumbre was his place in the world.

Fernando, your work will continue to bear good fruit. It will remain in the hands of your disciples with your same mystique, who will keep it alive in future generations. Surely, you will also have a special place in Heaven after doing so much good on Earth. 